\title{
Surface water management - a key (but often forgotten) component of pit slope stability management
}

\author{
JW Hall RPS Water Management, Australia
}

\begin{abstract}
When looking at the potential influence of pore pressure or groundwater on pit slope stability, and managing these to reduce the risk of slope failures, it is tempting to focus on in situ pore pressure and near pit groundwater flow processes. While surface water runoff is recognised as one of the broad regional sources of long term groundwater recharge, surface water management close to, and within pits, is often focussed on moving large volumes of runoff around, or from, pits with little thought given to how the surface water management system might impact on pit slope stability. It is not uncommon for leakage or spillage from water transfer ponds or water diversion structures to act as local recharge sources close to pit walls and limit the effectiveness of pit dewatering or pit wall depressurisation schemes. Essentially, poor surface water management can undo a lot of good work on dewatering and depressurisation that has usually taken a long time to achieve and at significant cost.
\end{abstract}

This paper presents a practical look at how various commonly adopted surface water management practices can impact on pit slope stability, including numerous examples, and provides a guide on how to avoid the traps of poor surface water management.

\section{Introduction}

There are many components to overall mine water management. These include securing a water supply, maintaining dry working conditions within the pit and around the general mine site, the discharge and management of tailings slurries, and minimising the impact of seepage from any number of mine site sources on the local and regional environment. Most, if not all, of the various components of overall mine water management are interrelated and efficient and cost effective mine water management requires an integrated approach.

However, while most mining operations strive to achieve integrated water management, the key drivers and responsible persons for individual components of mine water management are often different. This can lead to conflicts in the specific aims and outcomes of some mine water management initiatives. A common example of this, in the author's experience, is the largely unintended but significant impact of some surface water management practices on pit slope stability and slope stability improvement programmes. In most cases, such situations have arisen from a lack of understanding (on all sides) of the potential impacts of surface water on pit slope stability.

The following sections of this paper present:

- Brief outlines of the objectives and methodologies of surface water management and pit slope stability management - essentially the requirements and drivers.

- Examples of how some surface water management practices can negatively impact on pit slope stability management.

- Guidelines on how to avoid such impacts by the adoption of integrated mine water management practices.

The paper presents examples of surface water impacts on pit slope stability management from the author's experience (although the sites remain un-named). 


\section{Water management - key requirements and drivers}

\subsection{Surface water management}

Surface water management requirements around a mine site could include any of the following:

- Diversion of existing rivers and creeks to prevent flooding of mine infrastructure.

- Diversion of existing rivers and creeks around the mine (or parts of the mine infrastructure) to maintain downstream flows.

- Bunding to keep river, creek and/or lake water away from mine infrastructure where diversion is not possible (or cost effective).

- Bunding and diversion of sheet runoff around mine infrastructure to reduce the potential for mobilising sediment from disturbed mine areas.

- Drainage systems for potentially sediment laden internal stormwater runoff to sediment control facilities.

- Pumping of accumulated runoff from pit floors (or catchment berms) to the surface, for discharge to local rivers and creeks or to mine dams.

- Construction of water storage dams for water supply and/or environmental purposes.

The key driver for the diversion requirements is to move generally large volumes of water from point $A$ to point $B$ as quickly, and cost effectively, as possible. To do this, surface water diversion schemes will attempt to make best use of natural topography (i.e. follow low ground as much as possible) to reduce construction costs. Similarly, bunding will make best use of existing topography. For pit dewatering (runoff control), the key driver is to remove often large bulk volumes of water from the pit as quickly and cost effectively as possible.

However, in meeting these key drivers for surface water management, conditions could be created that will adversely affect pit slope stability management.

\subsection{Pit slope stability management}

The pit slope stability driven components of mine water management largely relate to groundwater and pore pressure management, and water management requirements could include any of the following:

- Active (or advanced) dewatering to intercept groundwater flows to the pit and lower the water table around the pit.

- Passive dewatering to manage residual groundwater inflows to the pit (this then forms a part of pit surface water management requirements).

- Passive pore pressure reduction by natural drainage of groundwater (pore water) to pit walls/floor (and to the passive dewatering system) or to active dewatering bores.

- Active pore pressure reduction by way of depressurisation schemes (including drain holes or drainage adits/galleries).

In the context of this paper, the last two requirements are the most important. Reducing pore pressure results in an increase in rock/shear strength and an improvement in pit slope stability.

The key driver for pore pressure reduction is to reduce pore pressure in a timely and cost effective manner to achieve, and maintain, pore pressure at levels that meet pit slope design criteria. However, it is possible that achieving or maintaining design pore pressures can be compromised by some surface water management practices. 
There are also some direct surface water implications for pit slope stability management which relate to the physical erosion of pit walls by surface water flow within the pit.

\section{Implications of some surface water management practices}

As outlined in Section 2, the individual drivers for surface water management and pore pressure management both have technical and cost effectiveness goals. However, when the technical goals are considered individually, and as suggested in Section 2.1, it is very easy for some surface water management practices to negatively impact on pore pressure management, while meeting all of the key goals of surface water management.

In practice, pore pressure management is often difficult and time consuming. Investigations and design studies take time and, typically, implementation takes time. Pore pressure generally becomes an issue when the permeability of the pit walls is low and the rock mass and joints are slow draining. Often the only way to manage (cost effectively) excess pore pressure is by the use of horizontal or sub-horizontal drain holes. These are drilled from the pit floor as the pit develops over the life of mine. There are other depressurisation methods available (e.g. drainage adits/galleries and directional pumping/drainage holes) which can be installed from the surface ahead of mining; but these are very costly and would be beyond the reach of many operations, logistically and cost-wise.

To make pore pressure reduction cost effective, it is important that there are no artificially applied constraints to achieving or maintaining the target levels of pore pressure reduction. However, surface water infiltration is one of the key groundwater recharge processes that contributes to, pore pressure in the first place. Any surface water management practice that results in enhanced recharge close to the pit can either constrain the effectiveness of pit wall depressurisation measures (particularly when the surface water management system has been in operation prior to pit development) or, and worse, result in the reversal or 'undoing' of previously achieved dewatering.

Examples of how this can occur are outlined in Sections 3.1-3.5.

\subsection{River and creek diversions}

When practical diversion alternatives are not available, the optimum route of a pit diversion channel (in terms of logistics and construction costs) is very close to the margins of the pit, along the topographically lowest terrain with the same drainage valley. The implication and consequences of diversion channels close to pit crests (and examples) include the following:

\subsubsection{Ongoing groundwater recharge}

The mere presence of surface water around the pit crest (during and immediately after rainy seasons) provides a source of recharge to soil and rock units which outcrop/subcrop beneath the diversion channel. An example of this is as follows:

- Gold mine in Tanzania - a holding dam was located well upstream of the pit with a spillway overflow channel which passed around the pit crest. The diversion channel was excavated into a laterite profile and designed (slope and width) to convey any spillway discharge quickly past the pit. During an extended dry period, rill material (soil and rock) had blown or fallen into the diversion channel and vegetation had taken root. When the dam eventually spilled during a wet year, discharge water was held up (ponded) in the rill and vegetation. Significant infiltration resulted in the re-wetting of the previously drained laterite profile and a pit wall failure.

The main issue in the above example was not the diversion channel as such. The potential consequence of the location of the channel had been recognised and the channel was designed to reduce the potential for recharge to the laterite profile. The problem arose because the diversion channel was not being maintained. 


\subsubsection{Pit flooding}

If the diversion bund between the pit crest and the diversion channel breaches, or the ground conditions between the pit and the diversion channel are not suitable, then the pit can be flooded. In part, this then becomes primarily a dewatering issue rather than a pore pressure issue, but the uncontrolled flow to the pit can create unstable pit slopes and recharge pit walls. Examples of this include:

- Gold mine in Cote d'Ivoire, Africa - a major diversion channel was excavated next to the pit crest and into permeable transition zone material. During the first wet season river flow, surface water short-circuited to the pit via the permeable transition zone and flooded the pit.

- Coal mine in Victoria, Australia - the bunding between a major river diversion and the pit breached and the full flow of the river diverted into the pit.

However, it should be noted that the trigger for the breach in the second example was a pit wall failure that was, in part, triggered by the discontinuation of active pit dewatering. This example could be considered as reflecting the impact of pit slope stability management on surface water management (and not the other way around), although recharge to the pit walls from the river diversion would have likely played some role.

\subsection{Water retention dams}

The implications of water retention dams close to pit crests are similar to those of diversion channels, in terms of providing a source of recharge to the underlying soils and rocks. However, such structures tend to hold water for longer periods of time and thus, the impacts are more prolonged.

An example of this is:

- Copper/gold mine in New South Wales, Australia - the pit intersected a major creek and there was no practical way of installing a diversion channel, thus a holding dam was constructed. The dam was designed with an automatic (dam water level driven) pump-out system. During a prolonged dry period, the pump-out system was removed. During the first 'wet' year, the dam filled and there was obvious recharge to a key pit slope (one which had been subject to many years of depressurisation effort), which elevated pore pressures to above design levels.

In this example, the presence and location of the dam was unavoidable; however, the potential consequences on pit slope stability, of water in the dam, had been recognised and a pump-out system designed to manage this. The issue arose from not operating the dam as designed.

\subsection{Water storage dams}

The implications of water storage dams close to pit crests are similar to those of diversion channels and water retention dams, where they can provide a prolonged source of recharge to the underlying soils and rocks.

An example of this is:

- Gold mine in Tanzania - a local topographic depression just behind a pit crest was used as a transfer dam for pit dewatering discharge and a source of dust suppression water. The dam was just above a slope that had been depressurised to improve its stability. This resulted in a significant increase in pit wall pore pressures.

In this example, an uninformed decision was made to locate a dam in a poor location from a pit slope stability management perspective. 


\subsection{Pit dewatering systems}

This refers to the sump pumping systems designed to raise water to the surface. There are a number of potential implications of this for pit slope stability management which all relate to infiltration of water from the dewatering system into the ground, and the consequent increase in pore pressures. Specific mechanisms include:

- Leaking pipe joints or valves.

- Seepage from dams/ponds at the pit crest.

- Seepage from transfer dams or pumping stations within the pit.

The first point is a maintenance issue (which could be the subject of a standalone paper) and the second is illustrated in Section 3.3. Examples of the third point are the following:

- Industrial/precious mineral mine in Western Australia, Australia - the in-pit dewatering transfer pumping station used a series of old containers as transfer ponds. However, as dewatering rates increased (and also due to some mismatch in pumping capacities) the containers were allowed to overfill and spill into an unlined pond area excavated into relatively permeable material. This resulted in rapid recharge to underlying rocks and significant fluctuations in pore pressures in the lower pit slope.

- Uranium mine in the Northern Territory, Australia - an unlined pit dewatering transfer pond and dust suppression water storage was excavated into highly weathered clay material adjacent to the main haul ramp. Infiltration from the pond re-wet a large area of clay (which had previously been the subject of a long tern drainage programme) resulting in unstable ramp conditions.

Both of the above are further examples of uninformed decisions being made to adopt a surface water management practice that has significant consequences for pit slope stability management. In the first example, an effective system had been designed, but then operated beyond its design capacity resulting in an impact on pit slope stability management.

\subsection{River or lake bunding}

Where it is not possible to divert surface water around a pit (e.g. where the pit has been developed within a permanent river of a lake), bunding will be required to keep the permanent surface water at some determined distance from the pit crest. A key consideration in this regard is the presence and location of old and ungrouted exploration drill holes. These ungrouted holes can become pathways for focussed pit wall and groundwater recharge. If this is not recognised, then the bunding stand-offs may not be sufficient. An example of this is as follows:

- Gold mine in Western Australia, Australia - there are multiple pits within a broad salt lake environment, with numerous bunds which form both access roads and lake bunds. These are typically pond water. At one pit a pumping system was installed to keep pond areas dry above the outcropping footwall sequence where there were known to be ungrouted drill holes. This pumping system was removed and the ponds were allowed to flood, which resulted in several minor failures in the footwall of the pit due to re-wetting of weak rock.

This is another example of where the potential implications of surface water have been recognised and steps taken to reduce the impact, but the system was not operated as designed.

\section{$4 \quad$ How to avoid problems - guidelines}

The solution to the issues outlined in the previous section is simple in concept, but can be difficult to implement unless there is top-down support and bottom-up commitment. They key to reducing the 
potential for any component of mine water management on other components is to develop and implement an integrated mine water management plan. Key elements of such a plan include:

- Recognition, and clear description, of all of the water management components that need to be addressed. This would include identification of all water risks and water management measures required to manage the risks.

- Clear communication of the key requirements of, and drivers for, each component of the overall mine water management system.

- Assessment of the impacts of the design (or modifications to the design) of any one component of the water management systems on other components.

- Authorisation of designs or design changes by those who might be impacted. This should include operations personnel when water management design is being undertaken by mine development teams.

- Clear lines of responsibility, with responsibility resting with appropriate mine or company personnel.

Most of the above simply relates to effective communication. However, the last point is considered to be the most important, and often the one that is least implemented. At some point, when all the designs have been reviewed (and modified) and all the discussions around cost-benefit-impact have occurred, someone needs to make a decision as to whether to implement a particular design or design change. In the author's opinion, in many cases key decisions are made by the wrong people.

So, who are the 'right people' to make key water management decisions? A guiding principle should be that the decision is made by the person who could be most affected by the outcome.

In the context of the potential impacts of surface water management on pit slope stability management, the final decision on which surface water management options to adopt (where the options have critical implications for pit slope stability) should rest with the mine manager.

\section{Conclusion}

Surface water management plays a key role in the management of pit slope stability. While, the focus of hydro-geotechnical investigations tends to be on in situ pore pressures and near pit wall groundwater flow processes, it must be remembered that surface water is often the principal source of groundwater recharge, and thus is a key driver of pore pressure. Keeping surface water away from the pit crest and pit slopes is important.

However, historically, poor surface water management practices, or where the implications of surface water management on pit slope stability have not been adequately taken into account, have resulted in negative impacts on pit slope stability. Such practices, or the outcomes of such practices, have typically led to recharge by leakage or seepage from surface water management facilities resulting in increasing pore pressures and, often, the undoing the benefits of costly and time consuming depressurisation programmes.

It is concluded that the adoption of an integrated water management approach with clear lines of authority and responsibility driven by outcome rather than process will reduce the potential for poor surface water management decisions to adversely affect pit wall stability. 